\title{
El narcotráfico en la historia de las relaciones internacionales contemporáneas
}

\author{
María Eugenia Cardinale*
}

\section{ReSUMEN}

El artículo pretende comprender la evolución del consumo y tráfico de drogas a lo largo de la historia de las relaciones internacionales contemporáneas -1789-1991-, es decir, el contexto que posibilitó su surgimiento y expansión, identificando actores, canales utilizados y principales beneficiaros. Se consideran tres subperíodos dentro del largo plazo: 1) desde el Siglo XVIII a la Tercera Guerra del Opio -1860-; 2) Desde mediados del s. XIX hasta la Segunda Guerra Mundial y 3) Desde la posguerra -1945- hasta el fin de la Guerra Fría -1991-.

Las "drogas" son tan antiguas como las civilizaciones. Sin embargo, el circuito económico productivo de las mismas irrumpe como hecho internacional en un momento específico de la historia; cuyas claves serían: la expansión colonial/imperialista occidental, el crecimiento del comercio internacional, el desarrollo de la industrialización y la consolidación de un mercado mundial. Dichas sustancias transitarán de productos tradicionales de sociedades específicas a mercancías globales de consumo masivo en el siglo XIX.

\section{Palabras clave}

Historia; relaciones internacionales; narcotráfico; prohibición; hegemonía.

\section{w}

\section{TITLE}

Illicit drug trafficking in the history of contemporary international relations

\section{Abstract}

The article seeks to understand the evolution of consumption and drugs trafficking throughout the history of the contemporary international relations -1789-1991-, analyzing the context that made its emergence and expansion possible, identifying actors, principal links and beneficiaries. Will be considered three subperiods of time in the long term: 1 ) from the 18 th century to the Third War of Opium $-1860-; 2$ ) From middle 19th century up to the Second World war and 3) From the postwar -1945- up to the end of the Cold War -1991-.

The "drugs" are as ancient as the civilizations. Nevertheless, the economic productive circuit appeared as an international phenomenon in a specific moment of the history; marked by: the colonial / imperialistic western expansion, the growth of the international trade, the development of the industrialization and the consolidation of a world market. "Narcotics" will be transformed from traditional products of specific cultures to global goods of massive consumption in the 19th century.

\section{KEYWORDS}

History; international relations; illicit drug trafficking; prohibition; hegemony. 


\section{ntroducción}

Las sustancias psicoactivas son tan antiguas como las civilizaciones. Sin embargo, el narcotráfico -el circuito económico/productivo de las mismas- irrumpe como hecho internacional en un momento específico de la historia mundial, cuyas claves serían: la expansión colonial/imperialista occidental, el crecimiento del comercio mundial, el desarrollo de la industrialización y la consolidación de un mercado de alcance planetario. Dichas sustancias transitarán de productos tradicionales de sociedades específicas a mercancías globales de consumo masivo en el s. XIX.

A medida que avanzó la profundización de las capacidades industriales, tecnológicas y comerciales las sustancias psicoactivas fueron perfeccionándose; esto permitió diversificar la oferta y la demanda e incrementar el mercado de las drogas.

A su vez, el desarrollo del tráfico de drogas en tanto ilícito está íntimamente asociado a la intervención política. La prohibición de determinadas sustancias y la legalidad de otras crearon condiciones específicas para su despliegue. Por ello, es necesario conocer la evolución de la legislación internacional sobre el tema para comprender cómo se definieron estas sustancias, cuáles fueron consideradas ilícitas y cuáles los parámetros de penalización.

Puede esquematizarse de la siguiente manera:

"En la historia del consumo de drogas se asiste a una fase larguísima dominada por el consumo tradicional y una fase de dos siglos, desde el s. XIX hasta nuestros días, dominada por la mercantilización, por la producción por síntesis químicas y por el régimen de prohibición para algunas sustancias"1.

El presente artículo pretende comprender la evolución del consumo y tráfico de drogas a lo largo de la historia de las relaciones internacionales contemporáneas (1789-1991), en qué contexto fue posible su surgimiento y expansión, qué actores intervinieron, cuáles han sido los canales utilizados y quiénes sus principales beneficiaros. Para ello se identifican tres subperíodos dentro del largo plazo: 1) desde el s. XVIII a la Tercera Guerra del Opio -1860-; 2) desde mediados del s. XIX hasta la Segunda Guerra Mundial y 3) desde la posguerra -1945- hasta el fin de la Guerra Fría -1991-.

Dos elementos conexos a considerar se enmarcan en las correlaciones de poder internacional: por un lado, la consolidación de un sistema internacional de alcance planetario, con centro gravitatorio en Europa; por el otro, la respuesta política que suscitará ese mercado internacional de "drogas", el prohibicionismo, originado en EEUU y aceptado por la comunidad internacional a medida que aquel alcanzó estatus de potencia.

El análisis considera las estructuras internacionales como históricas, tal como las define Robert Cox, donde interaccionan tres fuerzas o dinámicas: las instituciones, las ideas y las capacidades materiales en tres niveles del mundo social -la producción, las formas de estado y los órdenes mundiales-2 ${ }^{2}$. Al desglosar cada una de esas fuerzas el autor define

1 SANTINO, Humberto y LA FIURA, Giovanni, Detrás de la Droga, Homo Sapiens, Rosario, Argentina, 1993, p. 11.

2 COX, Robert W., Approaches to world order, Cambridge University Press, Cambridge, 1996. 
como capacidades materiales, en términos dinámicos, las potencialidades organizativas y tecnológicas y en términos de acumulación, aquellos recursos - naturales, industriales, armamentos- capaces de ser modificados por las capacidades dinámicas y toda la riqueza que esto conlleva.

En cuanto a las ideas entiende que son de dos tipos: significados intersubjetivos compartidos, es decir, nociones comunes acerca de las relaciones sociales y políticas. En segundo término, las ideas pueden ser abordadas como "imágenes colectivas del orden social de diferentes grupos de personas"; mientras que las primeras son compartidas en una estructura histórica particular, las segundas pueden ser divergentes. Por último, Cox afirma que la "institucionalización es una forma de estabilizar y perpetuar un orden particular", una institución se convierte en reflejo de las relaciones de poder predominantes y promueve imágenes colectivas consistentes con las mismas ${ }^{3}$.

En el narcotráfico 4 puede distinguirse claramente cómo se vinculan las tres fuerzas identificadas por $\mathrm{Cox}^{5}$ en el mundo social. Si el orden social hegemónico debe ser entendido como la confluencia dominante de poder material, ideología e instituciones que modelan y sostienen formas específicas de órdenes mundiales, el papel que juega el estado allí es de intermediación - aunque autónomamente- entre las fuerzas sociales moldeadas por la producción y el orden mundial. A su vez, dicho orden puede ser comprendido como una "particular configuración de poder" determinada por el sistema de estados y la economía mundial ${ }^{6}$.

Durante todo el s. XIX asistimos a una fase de predominancia del libre comercio y producción de sustancias psicoactivas, acompasadas al crecimiento de la industrialización y las tecnologías aplicadas a su mejora. Las ideas predominantes, sustentadas por un orden internacional con hegemonía europea $y$, particularmente, inglesa, fundamentaban el desenvolvimiento del libre intercambio entre las naciones y regiones del mundo, la conquista/ ampliación de mercados y el aumento del número potencial de consumidores, cualquiera que sea el producto.

El quiebre se consolidará en el siguiente siglo, con un giro en el centro de poder mundial hacia Estados Unidos. Desde fines del s. XIX hasta mediados del s. XX presenciamos una etapa de transición del orden social hegemónico. El ascenso progresivo de EEUU marcó, frente al fenómeno de las drogas, la lucha contra la libre circulación de sustancias psicoactivas que logrará imponerse definitivamente vis a vis su capacidad de moldear el orden hegemónico, sustentado en un conjunto de propuestas prohibicionistas y en la creación de instituciones internacionales respaldatorias de ello. Siguiendo a Modelski, pueden definirse como regulares en la política mundial estas "transiciones" de poder, y precisamente el autor comprende que

3 CoX, Robert W., "Fuerzas sociales, estados y órdenes mundiales: Más allá de la Teoría de Relaciones Internacionales" en Revista de Relaciones Internacionales, n 24, Universidad Autónoma de Madrid, Octubre (2013)-enero (2014), p. 142.

4 Ver subepígrafe: Precisiones conceptuales.

5 COX, Robert W., "Fuerzas sociales, estados y...", op.cit.

6 DEVETAK, Richard, "Critical Theory" en BURCHILL, Scott et al, Theories of International Relations, Pallgrave Mcmillan, Nueva York, 2005, p. 152. 
la experiencia más reciente y significativa de ese proceso lo encontramos en la primera mitad del s. XX con el "traspaso" del poder mundial desde Gran Bretaña a EEUU? .

En ambas fases, que iremos desarrollando por subperíodos específicos, se trata de relaciones de poder internacional donde los estados más fuertes tienen capacidad de imponer, al resto de los actores, el cúmulo de ideas e instituciones prevalentes en el sistema, con un acoplado rol de preeminencia en las fuerzas materiales, en el mercado mundial. Consideramos:

"[...] un concepto de hegemonía que está basado en una conjunción coherente o acoplada entre una configuración de poder material -la imagen colectiva imperante del orden mundial -incluyendo ciertas normas- y un conjunto de instituciones que administran el orden con una cierta apariencia de universalidad - por ejemplo, no sólo como instrumento manifiesto de la dominación de un estado particular-"

Se trata de "la dominación y subordinación de la metrópoli sobre el entorno, del centro sobre la periferia, en una economía política mundial" ${ }^{\prime \prime}$. En específico para el tema bajo análisis, esta jerarquización internacional estará determinada por la división internacional del trabajo entre los lugares de producción de sustancias de origen natural-cannabis, coca y amapola-, base, estas últimas, para elaborar luego drogas farmacológicas como cocaína o heroína. Es en los territorios colonizados/subordinados de Asia, África y América Latina donde estos cultivos se han desarrollado tradicionalmente, mientras que el control del comercio y el desarrollo de industrias químicas y farmacéuticas han tenido su eje en los estados centrales.

Tal como lo ha definido Wallerstein, "la división axial del trabajo en una economíamundo capitalista divide a la producción en productos centrales y productos periféricos." Estos se distinguen entre sí por los grados de acumulación de ganancias, mientas que los productos centrales son cuasimonopólicos - protegidos por los estados fuertes - generando, por la innovación que comportan, riqueza extraordinaria; los productos periféricos son competitivos y, por tanto, generan menos valor que los anteriores. El intercambio es, en ese escenario, desigual y puede reconocerse una derivación geográfica en las relaciones centro-periferia ${ }^{10}$.

\section{Precisiones conceptuales}

Dado que no existe una significación globalmente aceptada para definir estos temas, consideramos "sustancia psicoactiva" - o droga - tal como la define la Organización Mundial de la Salud como toda "[...] sustancia que, cuando se ingiere, afecta los procesos mentales"11. Esto permite abarcar dentro del calificativo drogas no solo sustancias ilegales, habitualmente incluidas en este concepto, sino también una gama de sustancias legales como alcohol,

7 "[...] the experience of the modern world has been marked by a succession of "world powers" -Portugal, the Dutch Republic, Britain, twice, and the United States- exercising leadership in the global arena." MODELSKI, George, "Long Cycles in Global Politics" en WIENER, Jarod y SCHRIRE, Robert, International Relations, vol 1, UNESCO/EOLSS, UK, 2009, pp: 230-252 y p. 231.

8 COX, Robert W, "Fuerzas sociales, Estados...op.cit., p. 146.

9 Ibídem, p. 139

10 WALERSTEIN, Immanuel, Análisis de Sistemas-Mundo: una introducción, Siglo XXI Editores, México DF, 2005, p. 19.

11 OMS, Managment of Substance Abuse, "WHO Lexicon of alcohol and drug terms". Disponible en http://apps.who. int/iris/bitstream/10665/39461/1/9241544686_eng.pdf [Consultado el 13 de agosto de 2017] 
tabaco, café y una serie de productos medicinales - tranquilizantes, antidepresivos $-{ }^{12}$.

Lo que hoy conocemos como narcotráfico incluye un ciclo de producción, comercialización y consumo, como cualquier otra mercancía del modo de producción capitalista. Sin embargo, por la prohibición que existe sobre este mercado ilegal la segunda característica fundamental es la violencia asociada, al involucrar niveles de criminalidad ${ }^{13}$.

El narcotráfico es también de naturaleza geopolítica dado que actúa a escala global penetrando los campos políticos, sociales y culturales, no solo la dimensión económica del orden internacional. No están claros los límites donde precisar el inicio y el fin del fenómeno, y determinar qué elementos y actores pueden ser identificados dentro del circuito ilegal de drogas es aún fuente de controversia.

1. Primer período. Desde el s. XVIII a la fase imperial de las relaciones internacionales. Los s.s XVIII y XIX constituirán los tiempos de oro para el opio y sus derivados. Durante el s. XVIII comenzó la comercialización agresiva del mismo, en manos de Gran Bretaña, desde India y Persia hacia Asia y Europa.

En 1729 China prohíbe, por primera vez, el comercio de opio con los europeos pero no el cultivo de adormidera ${ }^{14}$, algo tradicional. Al extenderse el consumo de opio los comerciantes chinos empezaron a aceptar el jugo de adormidera como medio de pago, traído por los europeos con este fin, práctica que socavaba las reservas imperiales de metales ${ }^{15}$. En 1793 se prohíbe también el cultivo de adormidera en todo el territorio chino, otorgándole ventajas enormes al contrabando.

En 1803 es aislada en laboratorio la morfina, principio activo del opio. Los médicos alabarán esa droga llamándola el "medicamento de Dios", era recetada para todo tipo de malestares y enfermedades, incluso a los niños ${ }^{16}$.

\subsection{Primera guerra del opio: las drogas adquieren presencia internacional}

El comercio de opio en China había crecido inmensamente a pesar de la prohibición. En 1729 la importación clandestina ascendía a tonelada y media aproximadamente, ya para 1820, cuando la pena de muerte estaba decretada para traficantes y usuarios, el contrabando ascendía a 750 toneladas, dos décadas más tarde lo hará a $2.000^{17}$.

12 Ibídem. También SANTINO, Humberto y LA FIURA, Giovanni, Detrás de...op.cit., p.15.

${ }^{13}$ DE REMENTERÍA, Ibán, "Prevenir en drogas: paradigmas, conceptos y criterios de intervención", CEPAL, División desarrollo social, septiembre, Santiago de Chile, 2001, p. 35.

14 "De adormir, por su propiedad narcótica. 1. f. Planta de la familia de las papaveráceas, con hojas abrazadoras, floresgrandes, vistosas y terminales, y fruto capsular indehiscente del que se extrae el opio". Diccionario de la Real Academia Española. Disponible en www.rae.es [Consultado el 13 de diciembre de 2017]

15 ESCOHOTADO, Antonio, Historia elemental de las drogas, Anagrama, Barcelona, 1996, p 83. COURTWRIGHT, David T., "Una breve historia de políticas sobre drogas, o por qué declaramos la guerra a unas drogas y no a otras", History Faculty Publications, University of North Florida, 2012. Disponible en http://www.uniad.org.br/ interatividade/artigos/item/16849-una-breve-historia-de-poli\%CC\%81ticas-sobre-drogas-o-por-que\%CC\%81declaramos-la-guerra-a-unas-drogas-y-no-a-otras [Consultado el 07 de Mayo de 2017]

${ }^{16}$ ESCOHOTADO, Antonio, Historia elemental de...op.cit.

${ }^{17}$ Ibídem, p. 84. 
En Europa, por su parte, se estaban desplegando los cambios que desembocarían en la Revolución Industrial y los productores de manufacturas inglesas, aumentada su productividad, necesitaban nuevos mercados donde colocar sus productos y proveerse de materias primas. Gran Bretaña veía en el inmenso territorio chino una oportunidad única. Sin embargo, China habilitaba sólo un puerto para el comercio exterior mediante monopolización de una sociedad comercial, el Co-Hong. Además, no se le permitía a los extranjeros penetrar suelo chino y el comercio estaba gravado con altas tasas impositivas.

En 1838, como explica Renouvin ${ }^{18}$, la balanza comercial china comienza a dar saldos negativos y el Imperio, viendo la perjudicial influencia que ejercía el contrabando de opio, decide frenarlo por la fuerza ${ }^{19}$. Se bloquean factorías externas y los cargamentos de opio, entre otros, son destruidos. La respuesta de Gran Bretaña es el envío de una flota expedicionaria a las costas chinas y finalmente declara la guerra. El ejército chino tuvo un papel desastroso, fue vencido por un pequeño cuerpo expedicionario inglés. Esta guerra significó la irrupción definitiva de las drogas en la arena internacional.

En 1842 se firma el Tratado de Nankín permitiendo residencia a los extranjeros, estipulando la apertura de cuatro nuevos puertos al comercio y cediendo territorios a Gran Bretaña. China es obligada a pagar indemnización, disolver el Co-Hong y a abrirse al comercio mundial por medio de la violencia ${ }^{20}$. Con respecto al opio es destacable el pedido inglés de no levantar la prohibición, así evitaba tarifas de importación y continuaba obteniendo los beneficios del contrabando. Este conjunto de ventajas comerciales serán extendidas a otras potencias hacia 1844.

En relación a esto, Cox afirma que a mediados del s. XIX la supremacía mundial de Gran Bretaña, la pax británica, se fundaba primordialmente en su control sobre los mares, poder que no fue desafiado por otra potencia. Las ideas predominantes en ese orden social hegemónico eran las "normas de la economía liberal -libre comercio, el respaldo en oro, libre movimiento de capital y personas-", estas reglas alcanzaron una amplia aceptación facilitando "la expansión del prestigio británico" y dotando al orden mundial de una "ideología universalista", lo cual significó a estas normas como base para la armonía de intereses ${ }^{21}$.

\subsection{Segunda y Tercera Guerras del Opio}

En el transcurso entre la primera y segunda guerra del opio se produjo la revolución de los transportes - barcos a vapor y ferrocarriles - y la aparición de la máquina a vapor. Estos nuevos instrumentos, sumados a los del período anterior, terminarán por completar la Revolución Industrial. Surgían así nuevas perspectivas para el comercio que facilitaban la obtención de

\footnotetext{
18 RENOUVIN, Pierre, Historia de las Relaciones Internacionales Siglos XIX y XX, Akal, Madrid, 1989.

19 "Paradójicamente la ilegalidad, más que un instrumento de disuasión o mecanismo incriminatorio y represivo, se convirtió en uno de los factores de expansión y fortalecimiento del llamado narcotráfico, que como circuito productivo-comercial se benefició de ella en términos económicos, ya que el valor agregado a la mercancía, determinado por los riesgos que encierran su producción, transporte y comercialización, permitió la acumulación de capitales casi sin precedentes". En ROSSI, Adriana, "Narcotráfico, entre Ilegalidad, Legitimidad y Funcionalidad", ponencia presentada en la Conferencia Nacional sobre Políticas de Drogas, Visión y Actores del debate, 17-18 Septiembre, Buenos Aires, 2003, p. 1.

${ }^{20}$ RENOUVIN, Pierre, Historia de...op.cit., p. 156.

${ }^{21}$ COX, Robert, Fuerzas sociales, Estados..., op. cit., p. 146.
} 
materias primas y permitían una mejor localización de los centros productivos. Se produjo el desarrollo definitivo de la industria que se extenderá por todo el mundo occidental.

El comercio internacional adquiere gran relevancia en las políticas exteriores de los estados europeos -Gran Bretaña y Francia- y estadounidense ${ }^{22}$. La Segunda y Tercera guerras del opio estarán signadas por el interés de las potencias en conseguir apertura definitiva del comercio en territorio chino.

El debilitado prestigio imperial chino se vio afectado por la inestabilidad social derivada de los acuerdos comerciales con Occidente - en guerra civil, dos tercios del territorio imperial será controlado por los rebeldes-. Siguiendo a Renouvin ${ }^{23}$ debemos señalar que la importación de textiles afectó las tradicionales artesanías chinas y generó un fuerte desorden monetario, desestabilizando la relación entre las dos monedas circulantes: plata y oro. Este último era para los extranjeros el único medio de pago, depreciándose la moneda en plata utilizada por la población nativa.

Es en este contexto de debilidad imperial que tiene lugar la Segunda Guerra del Opio donde Gran Bretaña y Francia presionaron con medidas de fuerza para obtener el pago completo de las indemnizaciones previstas y una apertura económica mayor. El comienzo del conflicto es en 1856, para 1858 los gobiernos europeos presentaron un acuerdo que el gobierno chino se negó a cumplir en su totalidad; dicha negativa dará inicio a la Tercera Guerra del Opio en 1859 donde se intensificaron los esfuerzos militares europeos culminando en la toma de Beijing en 1860. El tratado de Pekín subsecuente estableció un nuevo estatuto para los extranjeros, con más libertades al interior y la apertura de once nuevos puertos.

En relación al opio, Gran Bretaña consigue anular las prohibiciones sobre la importación e imponer una nueva indemnización. Una consecuencia clave fue la expansión de la producción de opio a lo largo de todo el Sudeste Asiático. Los niveles de importación y consumo de opio en el Imperio Chino escalaron de 6,5 millones de libras en la década de 1840 a 9,5 millones en la década subsiguiente ${ }^{24}$.

\section{Segundo período - Del s. XIX a la Segunda Guerra Mundial: 100 años de expansión para las sustancias psicoactivas}

Desde la década de 1860 se producirá una expansión sin precedentes del poder europeo a nivel mundial. Reconfigurado el mapa continental comenzó una política de "reparto" del mundo:

"Hay que considerar que en 1800 los poderes occidentales [...] controlaban aproximadamente el 35\% de la superficie de la tierra. [...] Hacia 1914, [...] Europa poseía una cantidad total de casi el $85 \%$ de la tierra en forma de colonias, protectorados, dependencias, dominios y 'commonwealths'"25.

\footnotetext{
22 RENOUVIN, Pierre, Historia de...op.cit., p.122.

${ }^{23}$ RENOUVIN, Pierre, Historia de...op.cit., p. 225.

${ }^{24}$ MCALLISTER, William B., Drug Diplomacy in the Twentieth Century. An International History, Routledge, Nueva York, 2002.

${ }^{25}$ SAID, Edward, Cultura e Imperialismo, Anagrama, Barcelona, 1993, p. 41. Cita de Magdoff (1978).
} 
El capitalismo industrial, consolidado y evolucionando de manera acelerada en Europa, empujaba a la búsqueda incesante de tierras y mercados, al control de puertos y vías de navegación estratégicos que aseguren la libre circulación de mercancías ${ }^{26}$. Desde el último cuarto del s. XIX se inicia un proceso de cambio en la estructura histórica de hegemonía británica, afirma Cox, transición que culmina en la Segunda Guerra Mundial:

"[...] el poder británico decayó relativamente, perdiendo su indisputable supremacía en el mar, primero con el reto alemán y luego con el aumento del poder estadounidense; el liberalismo económico naufragó con el aumento del proteccionismo, los nuevos imperialismos y definitivamente con el fin del patrón oro; y el intento tardío y fracasado de una institucionalización internacional a través de la Liga de las Naciones, no apoyado por un poder dominante o una ideología ampliamente aceptada, colapsó en un mundo cada vez más organizado en bloques rivales de poder ${ }^{27}$.

De acuerdo a Eric Hobsbawm ${ }^{28}$, el acontecimiento más importante en el s. XIX es la creación de una economía global que penetró todos los rincones del planeta, creando una red de transacciones económicas, comunicaciones y movimiento de productos y seres humanos, incluyendo creciente movimiento de dinero. En este sentido, las drogas como mercancías legales producidas por las industrias químicas y farmacéuticas en expansión llegaron a estar disponibles en cualquier lugar del mundo con régimen de venta libre.

\subsection{Industria farmacéutica y consumo de drogas}

En Europa, la era industrial trajo aparejado el surgimiento de una masa proletaria que acudía a las ciudades en busca de trabajo en las fábricas. Las condiciones de vida eran miserables, las familias se hacinaban en los suburbios de las grandes metrópolis sin condiciones mínimas de salubridad y las horas de trabajo eran interminables, tanto para varones como para mujeres y niños. En este contexto es que puede entenderse el hábito a ciertas drogas por parte de estas poblaciones vulnerables. Así mismo, se ignoraban los efectos nocivos que podía producir el uso de ciertas sustancias y algunas de ellas eran utilizadas por las diferentes clases sociales. De hecho, cada estrato social tenía su droga dependiendo de los costos de las mismas ${ }^{29}$.

El primer gran fármaco del s. XIX fue la morfina y, como sucederá a lo largo de toda la historia de las drogas, las guerras fueron clave en su propagación. Esta droga se expandió de forma definitiva por su utilización en la guerra franco-prusiana -1870-, en hospitales de guerra, como calmante. De igual modo, su expansión en EEUU tuvo lugar durante la guerra civil desde 1861 a 1865: "Al finalizar la guerra de secesión americana alrededor de 45.000 soldados presentaban hábito a la morfina, al punto que se la conocía como army disease"(la enfermedad del ejército) ${ }^{30}$.

Si bien la morfina era vista como una sustancia de uso terapéutico y aún no había

\footnotetext{
${ }^{26}$ Ver WALLERSTEIN, Immanuel, Análisis... op.cit.

${ }^{27}$ COX, Robert, Fuerzas Sociales, Estados... op.cit., p. 147.

28 HOBSBAWM. Eric, La era del Capital (1848-1875). La era del Imperio (1875-1914), Crítica, Buenos Aires, 2012, p. 733.

29 SANTINO, Humberto, LA FIURA, Giovanni, Detrás de...op.cit., p. 46.

30 SANTINO, Humberto, LA FIURA, Giovanni, Detrás de...op.cit., p 51.
} 
dado muestras de dependencia fuerte, el opio empezó a considerarse peligroso por ser usado masivamente por los estratos más bajos de la población, asociado culturalmente a la pobreza como "droga de la miseria"31.

Hacia 1841 es descubierta en laboratorio la cafeína. El alcaloide de la coca fue aislado en laboratorio en 1859 y la cocaína fue descripta químicamente en 1862. El empleo farmacológico de la cocaína comenzó en 1868, utilizada principalmente como anestésico y alabada en los círculos médicos, fue propuesta como remedio para problemas de alcoholismo y morfinismo - al igual que la morfina lo fue para la dependencia al opio- constituyéndose en bien suntuario en Europa y Norteamérica ${ }^{32}$. Para la última década del siglo aparecerá en el mercado la Coca Cola que utilizaba concentrados de coca.

China, por su parte, vuelve a cultivar adormidera en el suroeste y pone en marcha programas de información y centros de atención para quienes presentaran hábito al opio. En 1890 el país producía el 85\% de su demanda interna de opio con lo que su comercio hacia China dejó de ser rentable. En respuesta, los misioneros occidentales propusieron el uso de morfina y heroína como solución para el hábito al opio, e Inglaterra y Alemania serán los abastecedores de estas sustancias ${ }^{33}$.

En 1898 la empresa Bayer lanza al mercado dos nuevos productos: la aspirina y la heroína. Esta última fue descubierta en laboratorio en 1874 y era un semisintético de la morfina, la diacetilmorfina. Sin embargo, entre sus capacidades se la reconocía como fármaco para la desintoxicación de dependientes a la morfina, un mercado atractivo dado el elevado número de consumidores ${ }^{34}$. Cinco veces más activa que la morfina, la heroína se lanzará con gran esfuerzo publicitario en todo el mundo y con régimen de venta libre, al igual que la aspirina, ambos presentados como analgésicos inmejorables. También se inicia, en estos años, la difusión de hipnóticos o somníferos.

\subsection{Primeros intentos prohibicionistas}

En esta etapa se consolida una tendencia originada a fines del siglo anterior, la delimitación de las funciones médicas y farmacéuticas como campo específico de acción donde no debían tener injerencia otros sectores. Las sustancias psicoactivas pasaron a ser paulatinamente tema específico de la medicina y de los agentes autorizados para su fabricación.

La industria farmacéutica suplantó a la antigua "artesanía farmacéutica", sustituyendo los productos naturales por sustancias químicas, que se podían producir en cantidades enormes y a bajo costo, y construyendo una red capilar de distribución de los fármacos. "[...]

\footnotetext{
${ }^{31}$ La morfina era utilizada por mujeres de clase media, por políticos de prestigio como Bismarck, por intelectuales y artistas, por lo que se consideraba que podía ser consumida diariamente sin mayores inconvenientes. No eran generalizados los casos de dependencia como con el alcohol. En ESCOHOTADO, Antonio, "Toxicomanías", 2003. Disponible en http://www.escohotado.com/articulosdirectos/toxicomanias.htm [Consultado el 10 de Marzo de 2017]

32 ESCOHOTADO, Antonio, Historia elemental...op. cit. GABANTXO, Kontxi, "Antecedentes históricos, situación actual y tendencias de consumo" en Cuadernos de Ciencia de la Salud, no 4, Sociedad de Estudios Vascos, España, 2001, pp: 139-158.

33 Mc ALLISTER, William B., Drug Diplomacy in...op.cit.

${ }^{34}$ SANTINO, Humberto, LA FIURA, Giovanni, Detrás de...op.cit., p 53.
} 
Se abrió camino la consciencia médico-científica de los peligros derivados de su uso"35.

Por otra parte, en EEUU se fortaleció progresivamente la tendencia conocida como "reacción puritana", que instaba a una vida sana sustentada en las virtudes de la sobriedad; profundamente nacionalista, opositora al crecimiento migratorio dentro del propio país, asociaban el vicio a las distintas culturas de inmigrantes y promovían una vuelta a los principios bíblicos cristianos ${ }^{36}$.

Así, fumar opio se vinculó a inmigrantes de origen chino llegados como mano de obra barata al oeste, donde se los acusaba de toda una serie de crímenes $^{37}$. De acuerdo a Escohotado ${ }^{38}$, se crearon varias asociaciones que se harán sólidas a inicios del s. XX, las dos principales: el Prohibition Party y la Anti-Saloon League. Ésta última incorporó en sus filas millones de miembros con el objetivo de una "América limpia de ebriedad, juego y fornicación".

La Asociación médica y la Asociación farmacéutica, en defensa de sus propios intereses, decidieron asociarse a la ola puritana y obtener así el control sobre la producción, distribución y prescripción de drogas. Se difundió la noción de peligrosidad en el uso de sustancias no controladas por el médico o garantizadas en su fabricación. En este sentido, disminuyeron las cantidades de opio y derivados disponibles para el público, comenzando la era del control sobre las drogas de origen natural y abriéndose paso paulatinamente a la prohibición.

Una comisión estadounidense, conformada por médicos y representantes religiosos, es la convocante a la Conferencia de Shangai en 1909, centrada en el opio ${ }^{39}$. Participaron 13 países: EEUU y China, Inglaterra, Francia, Alemania, Italia, Países Bajos, Portugal, el Imperio Austro-Húngaro; Rusia; Japón; Siam y Persia.

Los trabajos evidenciaron la contraposición entre dos grupos: EEUU y China por un lado, delegados ingleses y europeos por el otro. Los primeros reclamaban la prohibición del comercio internacional del opio, los segundos querían salvaguardar sus intereses en este comercio. Las nueve resoluciones finales, que no implicaban ninguna obligación y se limitaban a meras recomendaciones, constituyen el primer texto de derecho sobre la droga de alcance internacional ${ }^{40}$.

Las potencias europeas con colonias en el Este Asiático, productoras de opio, consiguieron la no obligatoriedad de las resoluciones. El gran ausente fue Turquía, uno de los principales productores. Gran Bretaña, por su parte, obtuvo la victoria de mantener las negociaciones bilaterales con China con respecto a su comercio de opio.

\footnotetext{
${ }^{35}$ Ibídem, p. 52.

${ }^{36}$ ARMSTRONG, Karen, Los Orígenes del Fundamentalismo en el Judaísmo, el Cristianismo y el Islam, ,Tusquets, Barcelona, 2004, p. 221.

37 COURTWRIGHT, David T., "Una breve historia de políticas...op.cit.

${ }^{38}$ ESCOHOTADO, Antonio, Historia elemental...op.cit., p. 99.

39 COURTWRIGHT, David T., "Una breve historia de políticas...op.cit.

${ }^{40}$ SANTINO, Humberto y LA FIURA, Giovanni, Detrás de...op.cit., p. 65.
} 
EEUU como potencia en ascenso, especialmente por su influencia en Asia-Pacífico, logra efectivizar la primera conferencia internacional contra sustancias psicoactivas de origen natural. En este momento de transición del orden hegemónico no logró establecer un conjunto de ideas restrictivas a nivel internacional frente los intereses de las potencias europeas que, favorecidas por la libre comercialización de opio, frenaron los impulsos prohibicionistas. Sin embargo, la capacidad de convocatoria a una conferencia de este tipo refleja el poder internacional ascendente de EEUU que logrará moldear las instituciones regulatorias de las drogas a nivel global décadas más tarde.

\subsection{Las drogas y la brecha entre el bien y el mal}

A los miedos sobre el difundido consumo de opio entre los inmigrantes chinos pronto se sumó el consumo de cocaína entre las poblaciones afroamericanas de EEUU. En 1910, el médico prohibicionista Wright denunció que los empleadores estadounidenses abastecían a sus empleados negros con cocaína para un mayor rendimiento laboral. Pocos años después circulaban historias acerca de actitudes peligrosas entre los afroamericanos en el sureste, percibidos como amenaza al orden social ${ }^{41}$. El objetivo concreto de estos discursos era obtener apoyo en el Congreso para la aprobación de la Ley Harrison -antinarcóticos-, que dotaría al gobierno federal de expandidos poderes para controlar la cuestión de las drogas ${ }^{42}$.

En los fundamentos de la prohibición pueden reconocerse cuatro fuentes. Moralmente se relaciona con la visión puritana. Quienes mantienen sobriedad son ciudadanos modelos, perfectamente integrados a la sociedad, no causan daños y no hacen peligrar su salud ni la de los otros. Las drogas ponían en crisis valores sagrados como la familia, las costumbres, aumentaban la criminalidad y por esto se volvían una amenaza social.

Los fundamentos sanitarios y sociales alegan la obligación del estado de proteger la salud pública. Asimila la toxicomanía a una epidemia, como enfermedad contagiosa y, en este sentido, la prohibición, al actuar de raíz, estaría evitando el "contagio" y salvaguardando el bienestar social ${ }^{43}$.

Fundamentos raciales:

"El sentido de los arquetipos raciales sobre la droga era y es localizar el epicentro de las drogas en el "afuera". Las drogas eran/son un contaminante extranjero en el cuerpo europeo [occidental], un peligro mortal a su pureza, para ponerlo en términos simbólico-antropológicos"44.

Se instaló definitivamente en EEUU la representación de las drogas y el alcohol como

${ }^{41}$ COURTWRIGHT, David T., "Una breve historia de políticas...op.cit. LÓPEZ RESTREPO, Andrés, "Por tu bien, y sobre todo por el mío: fundamentos y altibajos del prohibicionismo estadounidense" en Análisis Político, $n^{\circ} 46$, Universidad Nacional de Colombia, mayo-agosto, 2002. Disponible en http://biblioteca.clacso.edu.ar/ar/libros/ colombia/assets/own/analisis46.pdf [Consultado: 08/05/2017). Ver el texto de la ley completa en: http://www. druglibrary.org/schaffer/library/studies/cu/cu8.html [Consultado el 22 de noviembre de 2017]

42 Ibídem, p. 12.

43 SANTINO, Humberto, LA FIURA, Giovanni, Detrás de...op.cit., p. 63.

${ }^{44}$ GOOTENBERG, Paul, "Hablar como el Estado: Flujo de Drogas y discursos estatales de control", Apuntes de Investigación del CECYP, Año XIII, vol. 24, no 1, pp: 13-49. Disponible en http://www.apuntescecyp.com.ar/ index.php/apuntes/article/view/471 [Consultado el 20 de junio de 2017] 
un mal que se propagaba en la sociedad y debía ser combatido. Lo llamativo de este enfoque es que no se basó en análisis científicos o en índices estadísticos acerca de qué sustancias son más peligrosas y porqué, una tendencia que prevalece durante todo el período histórico analizado.

\subsection{La prohibición como parte del fenómeno de las drogas}

Previa aprobación de la Ley Harrison, se llevó a cabo en la Haya la Segunda Conferencia sobre drogas. Fue en 1912, convocada por EEUU, quien no consiguió una aceptación general. Alemania, Portugal, Holanda, Japón, Rusia, China e Italia

"acordaron limitar el uso de los narcóticos a fines solamente médicos y restringir la manufactura y el comercio de esas drogas a los requerimientos de tales usos. También coincidieron en cooperar, [...] penalizar la posesión y prohibir su venta a personas no autorizadas" 45 .

Francia, Persia, Siam e Inglaterra - que para esas fechas exporta ya cuarenta toneladas de morfina al año- lo suscriben bajo reserva.

Los contenidos se dividieron en tres: 1) referido al opio crudo, se deciden restricciones al comercio internacional y reglamentaciones sobre producción y distribución; 2) concerniente al opio procesado para fumar, acordaron suprimir gradualmente su fabricación y comercio; 3) referido al opio medicinal como morfina y sus preparados, se previeron reglamentos farmacéuticos de producción, venta y uso.

Las ratificaciones serán pocas, Francia estableció reservas para no restringir la venta de opio en Indochina, mientras que China restringe significativamente su producción de opio. Inglaterra aplicó políticas evasivas aumentándola ${ }^{46}$. Es paradójico que los intentos de control más enfáticos estén orientados al opio crudo y no a sus derivados como morfina y heroína, sustancias mucho más potentes y con efectos adversos más marcados. Claramente, la producción de estas drogas estaba en manos de las industrias farmacéuticas occidentales, generando importantes niveles de acumulación, mientras que el opio representaba una droga producida en la periferia, en los territorios coloniales o con menores niveles de desarrollo ${ }^{47}$.

La Ley Harrison es promulgada en 1914, y creó el Narcotics Control Department para regular la inscripción administrativa de fabricantes y dispensadores de opio, morfina y cocaína,

45 THOUMI, Francisco E., "La normatividad internacional sobre drogas como camisa de fuerza" em Nueva Sociedad, no 222, julio-agosto, 2009, p. 44. Disponible en http://nuso.org/articulo/la-normatividad-internacional-sobredrogas-como-camisa-de-fuerza/ [Consultado el 21 de junio de 2017]. Ver Texto completo de la Conferencia en http://www.filosofia.org/mon/dro/1912cio.htm [Consultado el 15 de noviembre de 2017]

${ }^{46}$ SANTINO, Humberto, LA FIURA, Giovanni, Detrás de...op.cit., p. 67.

47 Entre 1911 y 1914, Inglaterra exportaba a China 40 toneladas de morfina, Alemania comercializaba hacia ese país 10 toneladas de heroína, que por potencia equivalen a 10.000 toneladas de opio indio. ESCOHOTADO, Antonio, "Sobria Ebriedad", El País, 16 de Julio, 1994. Disponible en https://elpais.com/diario/1994/06/16/ sociedad/771717615_850215.html [Consultado el 30 de junio de 2010]. De acuerdo a Wallerstein, en una economía-mundo capitalista: "La función de cada estado es muy distinto vis-a-vis los procesos productivos dependiendo de la mezcla de procesos centrales-periféricos dentro de él. En los estados fuertes, que contienen un margen desproporcionado de procesos centrales, se tiende a priorizar su función como protector de los cuasimonopolios de los procesos centrales. En los estados muy débiles, que contienen un margen desproporcionado de procesos de producción periféricos, éstos son en general incapaces de hacer mucho para afectar la división axial del trabajo, y se ven de hecho forzados a aceptar el destino que les ha tocado en suerte". WALLERSTEIN, Immanuel, Análisis...op.cit., p. 20. 
así como restringió las cantidades disponibles y estableció sanciones. Los beneficiarios eran médicos y farmacéuticos que obtuvieron un sistema de rigurosa exclusividad para cocaína, opiáceos y cualquier otra droga bajo control.

A principios del s. XX, con el aumento de controles surgirá lo que se conoce como "acanallamiento", esto es, la experimentación con redes de distribución semi-legales de morfina y heroína por medio de farmacias complacientes o por correo. Este mercado, todavía no clandestino, organizó su demanda y oferta, sus mayoristas y minoristas ${ }^{48}$.

Por otra parte, entre 1920 y 1930, alrededor de 40.000 profesionales -médicos y farmacéuticos - serán encarcelados en EEUU por recetar o dispensar opio, morfina o cocaína. El nivel de corrupción creció, muchos policías se vieron involucrados en el negocio o bien fueron acusados de chantaje. Claramente, la realidad de las drogas estaba cambiando y complejizándose.

En 1920, como corolario a la fiebre prohibicionista, entra en vigor la Ley Seca oficialmente llamada Volstead Act, prohibiendo el alcohol, salvo para uso médico. Las consecuencias fueron desastrosas, en 1932 existían medio millón de nuevos delincuentes, corrupción a todos los niveles y habían muerto cerca de 300.000 personas por beber destilaciones no aptas para consumo humano ${ }^{49}$. Las mafias afianzadas en EEUU - Lansky y Luciano, jefes de las principales organizaciones criminales- al amparo del tráfico de alcohol, al derogarse la Ley Volstead -1933-, se vuelcan al tráfico de heroína recientemente prohibida en EEUU.

\subsection{El prohibicionismo se internacionaliza}

En 1919, en la sección 295 del Tratado de Versalles ${ }^{50}$, se incorporan los textos de la Conferencia de 1912, sumándose al régimen restrictivo de drogas mayor número de países miembros de Sociedad de Naciones ${ }^{51}$. La organización fue la encargada de ejecutar las medidas tomadas en materia de opio y otras drogas. En ese marco se convoca a la Conferencia de Ginebra en 1925 de la que EEUU y China se retiraron por su desacuerdo con los principios planteados. Surgirán dos convenios distintos: La primera convención, relativa al opio procesado, adopta un sistema de producción y distribución reglamentado por un monopolio de Estado como mecanismo de control. Francia y Gran Bretaña estuvieron delante de la propuesta. La segunda se aplica a tres sustancias psicoactivas naturales: opio, coca y cannabis y sus derivados. Los países firmantes debían proporcionar periódicamente información sobre sus necesidades médicas de estupefacientes y someter a autorización administrativa toda operación de producción, importación y exportación de drogas ${ }^{52}$.

Aquí se aplicaron, en forma general, los criterios de restricción del uso de estas sustancias con fines médicos y científicos entre los que se incorpora, por primera vez, la

\footnotetext{
48 SANTINO, Humberto, LA FIURA, Giovanni, Detrás de...op.cit., p. 53.

49 ESCOHOTADO, Antonio, Historia elemental...op.cit., p. 91

50 Tratado de Paz firmado por los vencedores de la Primera Guerra Mundial con Alemania, donde se adjunta en sus hojas la creación de Sociedad de Naciones.

51 TOKATLIÁN, Juan Gabriel (comp.), Drogas y Prohibición: una vieja guerra, un nuevo debate, Libros del Zorzal, Buenos Aires, 2009.

${ }^{52}$ Ver SANTINO, Humberto, LA FIURA, Giovanni, Detrás de...op.cit., p. 68.
} 
heroína. La novedad residió en la creación de un órgano consultivo internacional -Comité Central Permanente- a cargo de recibir la información solicitada a los estados. Con todo, el mercado negro de drogas crece en Europa y se repiten los parámetros que se venían dando en EEUU, sustancias adulteradas que provocan la muerte de sus consumidores. En España solamente, entre 1924 y 1928, se cuadriplica el contrabando de opio y cocaína una vez que comienza a aplicarse el control estatal sobre importaciones y venta ${ }^{53}$.

La siguiente conferencia fue la Convención para Limitar la Manufactura y Regular la Distribución de Drogas Narcóticas de 1931, que estableció un sistema de reporte obligatorio de países productores sobre la extensión de áreas cultivadas con coca y amapola, a fin de limitar la producción a necesidades médicas y científicas, y se preveían sanciones por incumplimiento. Por otra parte, aparecen limitantes a algunas sustancias sintéticas al restringirlas para uso médico.

La siguiente conferencia es en 1936, el Convenio para la Supresión del Tráfico Ilícito de Drogas Peligrosas. Se previeron formas de cooperación en el ámbito penal internacional como la extradición de traficantes. Así mismo se instó a los países a crear cuerpos de policía especiales para el tráfico y tenencia de drogas ilícitas ${ }^{54}$.

Dos elementos a destacar: por un lado, en términos de hegemonía internacional se evidencia la capacidad progresiva de Estados Unidos para imprimir un conjunto de normas al sistema internacional, especialmente luego del rol jugado durante la Primera Guerra Mundial. De otro lado, en el nuevo siglo los acuerdos para el control de sustancias psicoactivas se incrementan considerablemente, centrados en el opio. Esta será, hasta la actualidad, una característica medular del conjunto de reglamentaciones, las principales drogas determinadas como ilegales son las de origen natural y sus plantaciones. Sus derivados, al estar controlada su producción por compañías de los estados centrales, tuvieron menores restricciones para el comercio y producción durante esta etapa.

En los años treinta, según Escohotado ${ }^{55}$, comenzó a comercializarse un nuevo producto sintético, las aminas - anfetamina, metanfetamina-, presentadas en venta libre para todo tipo de males. Son estimulantes del sistema nervioso central, diez o veinte veces más activos que la cocaína y más baratos. Estas drogas se volvieron muy populares en Japón, más acordes a su cultura que los opiáceos consumidos típicamente en Asia. Durante la Segunda Guerra Mundial se difundirán masivamente en Europa, introducidas en la guerra civil española, se utilizaron por alemanes, italianos e ingleses al repartirlas entre sus tropas por su capacidad de quitar el sueño y el hambre.

\section{Tercer Período. El Orden Bipolar de 1945 a 1991 3.1 El gran negocio del narcotráfico}

Durante la Segunda Guerra Mundial las drogas jugarán un rol importante como estimulantes o tranquilizantes entre las tropas en conflicto y como medio de pago en algunos escenarios

\footnotetext{
53 ESCOHOTADO, Antonio, Historia elemental...op.cit., p. 115.

54 THOUMI, Francisco E., "La normatividad internacional sobre...op.cit., p. 44.

55 ESCOHOTADO, Antonio, Historia elemental...op.cit.
} 
donde el consumo de determinadas sustancias era muy fuerte. Las rutas de comercio de opio estaban interrumpidas por la guerra, fundamentalmente el abastecimiento de opio crudo desde Persia e India. Francia decidió, teniendo el monopolio estatal sobre la producción, incentivar a campesinos de Indochina a incrementar sus sembradíos de adormidera. El opio servía a los aliados como incentivo para la colaboración de las poblaciones nativas contra Japón y como medio de intercambio ${ }^{56}$.

Las etnias Meo dedicadas al cultivo de adormidera desde el s. XIX, en Laos, por decreto colonial francés recibieron un estatuto especial que les otorgaba privilegios en la producción de opio, reforzado en 1948 otorgándoles exclusividad. Crecieron notablemente las capacidades productivas: en 1942 alcanzó las 25 toneladas y para 1944 ascendía a 30. De las mismas, entre 15 y 25 eran destinadas al comercio internacional, aumentando los ingresos del estado colonial en momentos de escasez por la guerra. Para finales de la década el monopolio estatal cesó pero el negocio, en marcha, continuó en la ilegalidad ${ }^{57}$.

En Europa la conexión será con las mafias sicilianas en EEUU, los servicios secretos proponen un acuerdo a estos grupos para obtener ayuda en la invasión al Sur de Italia durante el conflicto; las mafias ganaban a cambio vía libre para el comercio de estupefacientes ${ }^{58}$. Las relaciones entre el estado y los grupos criminales asociados al tráfico ilegalizado de sustancias psicoactivas se tornarán complejas, multidireccionales y contradictorias.

En 1946 y 1948 se firmaron dos protocolos internacionales que incorporaron dentro de las sustancias controladas y limitadas algunas drogas sintéticas. Por otro lado, con la creación de la Organización Mundial de la Salud ${ }^{59}$ comienza un procedimiento de clasificación internacional de drogas.

\subsection{EI narcotráfico durante la Guerra Fría}

En la segunda posguerra se afirma la hegemonía estadounidense en Occidente, desplazando definitivamente a Europa. Siguiendo a Cox, es posible afirmar que

"la configuración del poder en la pax americana fue más rígida que aquella propia de la hegemonía previa, tomando la forma de alianzas -todas articuladas sobre el poder estadounidense- creadas con el propósito de contener a la Unión Soviética"60.

El mundo estaba dividido en dos bloques enfrentados, en lucha por la posesión y garantía de zonas de influencia; lograr la preponderancia de alguno de los modelos, capitalismo o socialismo, era el hecho dominante en las relaciones internacionales; un orden bipolar

56 JELSMA, Martin, KRAMER, Tom, "Síntomas de abstinencia: cambios en el mercado de las drogas del Sudeste Asiático", Drogas y Conflicto, Documentos de Debate No 16, Transnational Institute, Briefing Series, no 1, 2008, p. 4. Disponible en https://www.tni.org/files/download/debate16s.pdf [Consultado el 13 de julio de 2017]

57 SANTINO, Humberto, LA FIURA, Giovanni, Detrás de...op.cit., p. 165.

58 Mc COY, Alfred, The politics of heroin in Southeast Asia, New York, Harper Colopohon Books, 1973. ESCOHOTADO, Antonio, "La prohibición principios y consecuencias" en MELO RIBEIRO M., SEIBEL S., Drogas, hegemonía do cinismo, Memorial, San Pablo, Brasil, 1997.

59 Los aliados, vencedores de la Segunda Guerra, crean la Organización de Naciones Unidas en 1945. Entre los organismos asociados se encuentra la OMS.

${ }^{60}$ COX, Robert, Fuerzas sociales, Estados...op.cit., p. 147. 
cuyas cabezas eran EEUU y la URSS.

La estabilización de la configuración del poder estadounidense en el mundo no socialista creó las condiciones necesarias para una economía global donde aquél se reservaba el papel conductor. El conjunto de instituciones creadas, aún para la economía internacional, sustentadas en las ideas del "liberalismo revisado de Bretton Woods", fortaleció a las corporaciones estadounidenses. Además: "La pax americana produjo un número mayor de instituciones internacionales formales que la hegemonía anterior"61. Entre ellas encontramos el conjunto de prohibiciones y regulaciones a las drogas de alcance global.

Con respecto a las sustancias psicoactivas hacia 1948 se reanudó la conexión Medio Oriente/Francia/Estados Unidos en la cadena del narcotráfico: el opio proveniente de Turquía, refinado por la mafia corsa de Marsella era convertido en heroína y entregada a las mafias sicilianas para su distribución en el mercado estadounidense ${ }^{62}$. Para 1950 el nivel de consumo de heroína allí oscilaba entre 10 y 13 toneladas del cual un $80 \%$ provenía de Francia63.

En Asia, luego del triunfo de la Revolución Comunista china en 1949, a cambio de limitar la potencial expansión del comunismo en ese continente EEUU y Francia entablaron relaciones con grupos étnicos y minorías en el área denominada "Triángulo Dorado" - los límites entre Myanmar, Laos y Tailandia-, estableciendo un "cordón sanitario" en la frontera con China. Una sucesión de guerras civiles y conflictos sociales se desarrollarán en esos territorios entre rebeldes comunistas y gobiernos anticomunistas.

Los nacionalistas chinos, luego de su derrota, se vuelcan a la producción de opio para financiar sus actividades anticomunistas con base en Birmania -Myanmar-. Los cultivos en el altiplano de Shan aumentaron enormemente, y ese opio era enviado a Tailandia desde donde se abastecían los mercados del Sudeste Asiático. En palabras de un general del Kuomintang: "Para luchar, necesitas un ejército; un ejército necesita armas; y para comprar armas, necesitas dinero. En estas montañas, el único dinero es el opio"64.

Se ha denunciado que la CIA sostuvo la conexión en secreto con estos grupos. Así mismo, el servicio secreto francés continuó apoyando a los Meos en el negocio del opio, ahora ilegal, obteniendo soporte en milicias para su guerra anticolonialista en Indochina ${ }^{65}$. Estas conexiones afianzaron al Triángulo Dorado como núcleo de la producción de opio y derivados. Simbolizó, además, la preeminencia de la seguridad nacional frente a consideraciones morales o sanitarias -en vinculación a las drogas ilícitas-; la prioridad en la seguridad justificaba alianzas con sectores ilegales o criminales frente a la amenaza comunista internacional, el principal enemigo. Estas vinculaciones, ocultas a la ciudadanía, se reproducirán a lo largo de toda la Guerra Fría66.

\footnotetext{
${ }^{61}$ COX, Robert, Fuerzas sociales, Estados...op.cit.

62 BETANCOURT, Darío, GARCÍA, Martha, Contrabandistas, Marimberos y Mafiosos. Historia social de la mafia colombiana, Tercer Mundo Editores, Bogotá, 1994, p. 25.

63 SANTINO, Humberto, LA FIURA, Giovanni, Detrás de...op.cit., p. 83.

64 JELSMA, Martin, KRAMER, Tom, "Síntomas de abstinencia...op.cit., p. 52.

${ }^{65}$ ESCOHOTADO, Antonio, Historia elemental...op.cit., p. 133.

${ }^{66}$ Uno de los casos más conocidos refiere a las acciones de la CIA durante la Segunda Guerra de Indochina, aún
} 
Es Mc Coy quien ha realizado el más importante estudio pormenorizado sobre estas conexiones en Europa y Asia desde la Segunda Guerra Mundial. De acuerdo al autor, de tres formas se han visto implicados los agentes secretos estadounidenses en el tráfico de heroína: 1) siendo cómplices indirectos al aliarse en su lucha anticomunista con grupos implicados activamente en el tráfico; 2) induciendo el tráfico al encubrir a narcotraficantes de heroína y tolerando su involucramiento en el negocio; 3 ) sosteniendo una práctica activa de transporte de opio y heroína ${ }^{67}$.

Para la década de 1950 el negocio de las drogas estaba estabilizado y se reconocían dos conexiones principales: Marsella/La Habana/Nueva York y Medellín/La Habana/Nueva York. En Medellín emergieron los primeros laboratorios de procesamiento de cocaína, sin embargo, el centro de producción en laboratorios continuaba siendo Europa ${ }^{68}$.

Las drogas sintéticas legales, por su parte, siendo de libre venta comenzaban a crear hábito y aún se desconocían las consecuencias de su uso. Las anfetaminas, por ejemplo, eran de consumo habitual entre amas de casa, estudiantes y personas mayores. Solo en EEUU se elaboraban unas mil toneladas anuales; sin embargo, hasta la década de 1970 ningún gobierno apoyará el control internacional de estas sustancias, principalmente por la presión de los grandes laboratorios ${ }^{69}$.

Dentro de esta lógica las convenciones internacionales continuaron focalizadas en sustancias de origen natural. En 1953 se firma el Protocolo de Nueva York sobre los controles internacionales para los cultivos de adormidera; sólo 7 estados estaban facultados para continuar produciendo opio -Bulgaria, Grecia, India, Irán, Turquía, URSS y Yugoslavia-, con monopolio de estado y recibiendo inspecciones internacionales, previendo el embargo como sanción. Este protocolo será duramente cuestionado y recién conseguirá el número de ratificaciones necesarias en $1963^{70}$.

\subsection{Nuevas drogas, contracultura y legislación internacional}

El punto de partida para abordar la década de 1960 es la Convención Única sobre Estupefacientes de Naciones Unidas de 1961. Este será el texto que instale la prohibición definitiva sobre las drogas a escala universal. De la misma participaron 77 países y para 1990 era ratificada por 133 estados, aplicándose a 108 productos, entre los cuales el énfasis está puesto sobre tres

antes del involucramiento masivo directo de tropas de EEUU. Diem, que efectuó un golpe de estado y quedó al mando en Vietnam del Sur, aliado anticomunista de la potencia occidental heredó el negocio de tráfico de opio y derivados de su antecesor. "A instancias de la CIA, los hombres de Diem comenzaron a utilizar aviones norteamericanos para transportar armas y suministros en apoyo a las fuerzas del Kuomintang que resistían contra Mao y luchaban contra la guerrilla comunista en Laos. Las operaciones de regreso se utilizaron para cargar las aeronaves con opio, a la vista de todo el mundo, para financiar la naciente guerra en Laos y Camboya. Las compañías aéreas, establecidas por la CIA, fueron popularmente bautizadas como "Air Opium." Para 1963 el gobierno de Kennedy decretará la suspensión de esos vuelos. ATEHORTÚA CRUZ, Adolfo León y ROJAS RIVERA, Diana Marcela, "El narcotráfico en Colombia. Pioneros y Capos" en Revista Historia y Espacio, n 31, 2008.

${ }^{67}$ Mc COY, Alfred, The politics of heroin in Southeast Asia, Harper Colopohon Books, Nueva York, 1973, p. 15.

68 DEL OLMO, Rosa, Los discursos sobre la droga, Hisbol, Bogotá, 1988, p. 29.

${ }^{69}$ ESCOHOTADO, Antonio, Historia elemental...op.cit., p. 119.

70 TNI, "Las Convenciones de Drogas de la ONU", 2015. Disponible en https://www.tni.org/files/publicationdownloads/primer_unconventions_24102015-es.pdf [Consultado el 12 de agosto de 2017] 
componentes naturales y sus derivados: coca, opio y cannabis.

Se estableció la idea de las sustancias psicoactivas como amenaza social y económica, no sólo como daño a la salud individual; preveía, además, la eliminación total de las plantas naturales que permiten la elaboración de estupefacientes. En este sentido, la hoja de coca como elemento ancestral para los pueblos originarios americanos debía ser erradicada por completo, en un proceso gradual de décadas. Los mismos criterios se aplicarán para las plantaciones de cannabis. El modelo propugnado por EEUU, de atacar las fuentes de producción, es decir, la oferta de sustancias psicoactivas se convierte en paradigma internacional ${ }^{71}$.

Se estableció un régimen riguroso sobre las necesidades estatales para cada una de las sustancias implicadas en la lista de clasificación, fijando la producción, fabricación, exportación, importación, almacenamiento y consumo autorizado. Para ello, se emitirán certificaciones para los intercambios internacionales de las sustancias listadas. Quedaba, de todos modos, un vacío importante en relación a las medidas de control y sanción.

En el siguiente cuadro aparecen los listados sobre estupefacientes y sustancias psicotrópicas de las Convenciones Internacionales.

\section{Cuadro 1. Orden de peligrosidad de las sustancias elaborado en base a los 8 listados de las Convenciones de 1961 (estupefacientes) y de 1871 (sustancias psicotrópicas)}

\begin{tabular}{|c|c|c|}
\hline Listado & Convenciones & Principales sustancias clasificadas \\
\hline Listado IV & Estupefacientes & Heroína, cannabis, hachís... \\
\hline Listado I & Estupefacientes & $\begin{array}{l}\text { Opiáceos (opio, morfina, heroína...), } \\
\text { sustitutos morfinices de síntesis, } \\
\text { Coca, cocaína, cannabis, hachís... }\end{array}$ \\
\hline Listado I & Psicotrópicas & Mescalina, LSD, psilocibina, THC, MTP... \\
\hline Listado II & Estupefacientes & Codeína, propiram... \\
\hline Listado II . & Psicotrópicas & Anfetaminas, fenciclidina... \\
\hline Listado III & Psicotrópicas & Barbitúricos \\
\hline Listado IV & Psicotrópicas & Tranquilizantes (benzodiazepina) . . . \\
\hline Listado III & Estupefacientes & Preparados farmacéuticos... \\
\hline
\end{tabular}

Fuente: SANTINO / LA FIURA, 1993

El cuadro ha diso elaborado con los criterios de una segunda convención que complementará a la de 1961, de todos modos, a los efectos de precisar las sustancias y su interpretación por la comunidad internacional nos parece suficiente.

La década mencionada estuvo signada por grandes manifestaciones políticas y culturales, lideradas por jóvenes occidentales, contra el orden establecido en todos sus aspectos. Las drogas se tornaron un elemento contestatario al utilizarse colectiva y públicamente en esas manifestaciones; la novedad residía en su expansión entre jóvenes de clase media y alta. Ya no podía pensarse en los grupos asociados al uso de drogas como criminales, delincuentes o minorías. El boom en el uso de marihuana, asociado hasta aquí en EEUU a los inmigrantes mexicanos, hizo cambiar el paradigma del prototipo del consumidor,

\footnotetext{
71 Ver NACIONES UNIDAS, UNDOC, Convención Única sobre Estupefacientes, 1961. Disponible en https://www. unodc.org/pdf/convention_1961_es.pdf [Consultado el 25 de julio de 2017]
} 
de delincuente a enfermo ${ }^{72}$.

Este mercado de marihuana se abastecía por producciones latinoamericanas. Hasta 1965 el gran productor fue México, paulatinamente, por la mala calidad comenzó a ser reemplazada por marihuana jamaiquina. Contra esta sustancia tuvieron lugar dos operativos de erradicación realizados por Washington, en México y Jamaica, cuya consecuencia fue el desplazamiento de la producción de marihuana hacia Colombia. Asociada a esto se encuentra la inmigración intensiva de colombianos hacia EEUU desde 1965, donde entablaron contacto con otros grupos criminales, obtuvieron acceso a la banca internacional y conocieron las redes de distribución ${ }^{73}$.

Un factor clave en el crecimiento del tráfico de heroína en los EEUU fue la guerra de Vietnam -1962/1975-. No solo porque muchos de los soldados norteamericanos se habían vuelto dependientes al opio - un $15 \%$ de los militares- y sus derivados, sino también por la continuidad de la práctica seguida por la CIA de alianza con grupos narcotraficantes en su lucha anticomunista. Por otra parte, los grandes grupos criminales encargados del tráfico de heroína estaban corruptamente imbricados con los gobiernos de la zona, parte de los cuales eran aliados indispensables para la guerra anticomunista en el Sudeste Asiático.

El discurso divulgado desde la Casa Blanca y los medios de comunicación era conspirativo, se acusaba a China y la URSS de abastecer de drogas al mercado norteamericano a los fines de minar desde dentro la civilización occidental, sin embargo, la producción y tráfico por parte de gobiernos y grupos comunistas no llegaba a niveles que pudieran ser los únicos responsables de su exportación.

Es interesante mencionar la expansión del consumo de sustancias sintéticas no sujetas a prohibición. Barbitúricos, hipnóticos y ansiolíticos mantenían su condición de venta libre y eran de consumo masivo entre todos los grupos etarios ${ }^{74}$. Entre las drogas químicas consumidas en cantidad destaca el LSD 25, un alucinógeno difundido por artistas y utilizado para tratamientos psiquiátricos. Su prohibición data de 1968, inicio de un mercado negro de grandes proporciones, fácil de proveer ya que: "el LSD no requería cultivos, actuaba a millonésima de gramos, y era una droga que estudiantes avanzados - así como profesores de química - sintetizaban. Diez años después de su prohibición los iniciados en el LSD ascienden a 20 millones entre Europa y EEUU"75.

\subsection{Cambios en la economía internacional. Nuevos centros productivos ilegales}

En 1971 se llevó a cabo la Convención de Viena sobre Sustancias Psicotrópicas, firmada por 106 estados y focalizada, por primera vez, en sustancias sintéticas que fueron agrupadas en

\footnotetext{
72 Prevalecerán dos discursos, el médico-sanitario centrado en el estereotipo de la dependencia - que a partir de la Convención de 1961 reemplazará la idea de adicción-, y el discurso ético- jurídico, que difunde el estereotipo moral-delictivo. DEL OLMO, Rosa, Los discursos...op.cit., p. 33.

73 BETANCOURT, Darío, GARCÍA, Martha, Contrabandistas...op.cit., p. 47.

74 "Para 1965 en Inglaterra el número de dependientes asciende a 135.000, en Escandinavia el 73\% de los dependientes a drogas lo es a este tipo de sustancias, en EEUU se calculaba que el número de habituados era de 250.000". En ESCOHOTADO, Antonio, Historia elemental...op.cit., p. 122.

${ }^{75}$ Ibídem, p. 155.
} 
4 listas $^{76}$. El principal interés fue la regulación internacional sobre el LSD, incorporado a la lista I, quedando totalmente prohibida; las sustancias de la lista II y III requerían fiscalización internacional; mientras que los de la lista IV, reconocidos como de varios usos médicos y científicos, podían fabricarse y venderse con receta médica. Fármacos de gran principio activo como los barbitúricos, las aminas o hipnóticos, en las listas II y III, podrían ser dispensados con recetas simples pero requerían un cupo anual por país que debía ser notificado.

Asimismo, en 1972 se firmó el protocolo de Ginebra enmendando la Convención Única y haciéndola más rigurosa. Reforzó las medidas de control -sobre cultivos- y de extradición, así como extendió la severidad con que eran tratados los cultivos de adormidera hacia sustancias de síntesis ${ }^{77}$.

La droga que generó las mayores alarmas durante esta década fue la heroína, principalmente en EEUU dada la expansión del consumo interno posVietnam. Mientras que en 1962 los consumidores se estimaban en un $0.5 \%$ de la población total, en 1979 el porcentaje ascendía a 33\% ${ }^{78}$. En lucha contra la "epidemia" de heroína, Nixon lanza una campaña contra plantaciones de adormidera turcas en 1972; una vez más, la consecuencia fue la ampliación aún mayor de la producción de opio en el Triángulo Dorado. Un efecto que se reproduce hasta la actualidad, la demanda no se interrumpe por las acciones sobre la producción, sino que cuando se corta uno de los brazos de la oferta, el abastecimiento se desplaza territorialmente pero no desaparece. Este mecanismo se conoce como "efecto globo".

La Medialuna Dorada - Pakistán, Afganistán e Irán- inició su producción más intensiva de adormidera, sobre todo Pakistán y Afganistán, al disminuir abruptamente los cultivos turcos - hasta 1955 el principal productor era Irán-. De todos modos, tendrán un mayor papel en el tráfico internacional una vez iniciada la guerra contra la invasión soviética en Afganistán en 1979.

En América Latina, como reacción a este desabastecimiento en el mercado norteamericano de heroína, surgirán dos nuevos actores. Por un lado, México que inicia su producción de opio y derivados para ese mercado con heroína de baja calidad y, por otro, la Región Andina.

Es necesario precisar los cambios producidos en la económica internacional, en recesión y agotamiento del modelo de acumulación. Se consolidaba la economía de servicios, acentuándose la caída de la industrialización; así mismo, las dos crisis petroleras del subperíodo generan un exceso de divisas internacionales que fueron volcadas masivamente al sistema financiero, creciendo su rol internacional. De otro lado, desde la década anterior se desarrolló la inversión transnacionalizada de capitales, ampliando los lugares y modos de producción en diferentes territorios a escala mundial, dinámica consolidada en esta fase.

\footnotetext{
76 Ver cuadro en página 22.

77 WOODIWISS, Michael, BEWLEY-TAYLOR, David, "La Componenda Global. La construcción de un régimen global de control", Transnational Institute, Briefing Series, Programa Crimen y Gobalización, no 3, 2005. Disponible en https://www.tni.org/files/download/crime2s-1.pdf [Consultado el 01 de agosto de 2017]

${ }^{78}$ WOODIWISS, Michael, BEWLEY-TAYLOR, David, "La Componenda Global...op.cit.
} 
Se deterioraron los términos del intercambio perjudicando enormemente a los países periféricos, la mayoría de ellos recientemente independizados, productores de materias primas cuyos precios disminuyeron de manera abrupta. Durante toda la década en América Latina se intensificará el desempleo y la inflación. Todos estos cambios confluyeron para favorecer un negocio ilegal cuyas proyecciones internacionales estaban en aumento.

La Región Andina comenzó su producción extendida de cocaína hacia mediados de 1970 como respuesta a la caída de precios de materias primas. El auge de las plantaciones del arbusto de coca surge en Perú y Bolivia en ese escenario. Si bien es ancestral la producción y uso de coca en ambos territorios, en el caso de Perú su incremento se asocia al período de producción y comercio legal de la cocaína. En particular, "en el transcurso de la década la cantidad de hojas de coca producida en Bolivia tuvo un incremento repentino: subió de 6.800 toneladas en 1971 a 16.817 en 1977, correspondientes a 62 toneladas de sulfato de cocaína"79. Sin embargo, Gootenberg especifica que la dispersión y crecimiento de la Región Andina como el corazón de la producción mundial de cocaína está directamente vinculada a la criminalización de la misma por parte de EEUU iniciada en la década de $1950^{80}$.

Se ha señalado que el gobierno dictatorial de Banzer en Bolivia conocía y fomentaba este negocio, siendo los propios militares gobernantes partícipes en aquel. Señalamos este caso porque evidencia otra variable de vinculación del estado con el narcotráfico, determinada por la interdependencia entre ambos. La capacidad de corrupción de las ganancias del negocio ilegal hace de los estados un blanco de complicidad, a pesar de sostener una política oficial represiva contra el mismo.

En Colombia la inserción como productor de sustancias psicoactivas se inició con la marihuana, tal es el caso del cártel de Medellín que pronto fue impulsado a dedicarse a la cocaína por las mafias norteamericanas residentes en Panamá81. Otro cártel relevante es el de Cali, surgido al amparo de una cultura de contrabando en esa región cuya proximidad con el Amazonas brindaba facilidades para acceder a cultivos y al tráfico ilegal; aquel procedió a apropiarse de grandes extensiones de tierra e introdujo al país la pasta base - necesaria para la transformación de la cocaína- desde Perú y Bolivia ${ }^{82}$.

Además, los avances tecnológicos aplicados a cultivos convirtieron a California, en 1978/1979, en centro de producción de la marihuana de mejor calidad a nivel mundial, la "sin semilla".

\subsection{Neoconservadores y guerra transnacionalizada a las drogas}

Con la administración Reagan, desde 1981, se consolida en Occidente el cambio del modelo

\footnotetext{
79 SANTINO, Humberto, LA FIURA, Giovanni, Detrás de...op.cit., p. 121.

80 GOOTENBERG, Paul, "Cocaine's long march North" en Latin American Politics and Society, vol. 54, no 1, Primavera, 2012, pp: 159-180.

${ }^{81}$ BETANCOURT, Darío, GARCÍA, Martha, Contrabandistas...op.cit., p. 70.

82 "Así como la mafia norteamericana moderna se inicia con inmigrantes sicilianos, se monta sobre el licor ilegal y se fortalece con el control sobre los narcóticos, la mafia colombiana se construye con la gran migración de colombianos a Estados Unidos, muy fuerte en los años setenta, y se consolida a través del control sobre la producción y distribución de cocaína. [...] Sólo a partir de esto se constituyó una mafia como tal". Ibídem. p. 138.
} 
de acumulación. Su epicentro residía en el mercado, en el achicamiento del estado -en términos de reducción de gastos - y la liberalización del comercio y finanzas internacionales. Era el fin del estado de bienestar y la recuperación del liberalismo, ahora transnacional. Por otra parte, esta corriente neoconservadora tenía sus cimientos en un discurso moral, en la recuperación del valor de la familia como base de la sociedad y de la civilización occidental y cristiana.

Las drogas, en ese marco, se volvieron intolerables y Washington les declaró la guerra83. El "enemigo", situado en la oferta, inundaba el mercado con sustancias psicoactivas y expandía el consumo, amenazando a la sociedad y sus valores tradicionales, con capacidad de desestabilizar el estado democrático y, en este sentido, amenazando la seguridad nacional. La sustancia que más temor generaba era la cocaína por los altos índices de consumo en todos los estratos sociales.

La erradicación forzosa de cultivos y la interdicción -interceptar los cargamentos de drogas antes de que lleguen a las fronteras - serán las tácticas principales de esta estrategia de ataque en las fuentes, con especial énfasis en los países de la Región Andina productores de cocaína. Se transnacionaliza definitivamente la "guerra a las drogas". El fundamento consistía en dificultar la producción y el tráfico generando desabastecimiento, esto obligaría a los carteles a aumentar los precios, al tiempo que disminuiría la pureza, desincentivando el consumo. A pesar de ello:

"[...] la cantidad circulante de esa droga en EEUU alcanza tales proporciones que en 1984 su precio bajó dos tercios. En 1988, los precios habían bajado otros dos tercios, situándose un kilo en 40 mil dólares, cuando una década antes en la 'permisiva' época de Carter valía cinco veces más"84.

No obstante "la guerra", EEUU se había convertido en uno de los principales centros de lavado de dinero, el caso más conocido se daba a través de bancos en Miami donde grupos criminales controlaban parte del sistema financiero ${ }^{85}$. Con respecto al funcionamiento del circuito ilegal, el mercado se volvió oligopólico. Se estructuró en torno a una división internacional del trabajo en cada región productora.

En el Triángulo Dorado la mayor cantidad de la cosecha provenía de la región Shan. Laos tenía asignado un rol menor como productor de materia prima y de refinación del opio. La gran parte transformadora era Tailandia, donde se producían las mercancías de laboratorio como heroína y era, a su vez, la base de despegue para el mercado internacional ${ }^{86}$.

En la Medialuna Dorada la división se daba básicamente entre Pakistán y Afganistán. Entre ambos, el primero se ocupaba de la refinación y comercialización mientras los cultivos de adormidera se centraban en el segundo.

\footnotetext{
${ }^{83}$ La primera administración en hablar de guerra a las drogas es la de Nixon, con respecto a la heroína.

${ }^{84}$ ESCOHOTADO, Antonio, Historia elemental...op.cit., p. 188.

85 GOOTENBERG, Paul, "Hablar como el Estado...op.cit.

${ }^{86}$ SANTINO, Humberto, LA FIURA, Giovanni, Detrás de...op.cit., p. 104.
} 
En la Región Andina los cultivos se expandían principalmente en Perú y también en Bolivia, en ambos se realizaba el primer tratamiento a la hoja de coca para convertirla en pasta base. La refinación y transformación en cocaína pertenecía a Colombia, allí también se concentraba la base de comercialización internacional. Ecuador era el principal país de tránsito, desde donde se embarcaban los despachos de droga hacia el mercado norteamericano ${ }^{87}$.

Mientras crecía a nivel internacional la acción represiva sobre los centros de producción de drogas de origen natural surgen las denominadas drogas de diseño. Enteramente sintéticas y creadas para generar efectos específicos sobre el consumidor. La particularidad es su nacimiento dentro de la prohibición, a diferencia de todas las demás sustancias mencionadas que eran de uso tradicional en determinadas culturas o surgían dentro de un marco de legalidad como productos terapéuticos. La difusión de sustancias sintéticas dependía de los originales que copiaban en tanto sucedáneos de drogas de origen natural restringidas ${ }^{88}$.

En este escenario de extensión y desarrollo del negocio ilegal de sustancias psicoactivas se aprueba en ONU la Convención contra el Tráfico Ilícito de Estupefacientes y Sustancias Sicotrópicas de 1988; la misma recoge, nuevamente, la visión estadounidense sobre la problemática del narcotráfico. A partir de ahora Naciones Unidas reconoce a la oferta como una amenaza a la seguridad y soberanía de los estados, profundizándose la legitimidad hegemónica de EEUU, al incorporarse sus ideas en tanto universales a través de instituciones internacionales. Buscando un mayor nivel de intensificación para la prohibición:

"[...] la Convención de 1988 amplió de forma significativa el alcance de medidas contra el tráfico, incorporó cláusulas para controlar el blanqueo de dinero, embargar los bienes de traficantes de drogas, permitió la extradición de grandes traficantes y la mejora de la cooperación legal entre países. La presión ejercida por los estados productores en la Conferencia Internacional ayudó a garantizar que también se incluyera la penalización de los usuarios de drogas por posesión ${ }^{89 " .}$

Por último, es significativo que el principal consumo se daba en las sociedades occidentales. La cuestión de la demanda era una realidad que pesaba sobre todo en EEUU y Europa, mientras que la producción de drogas de origen natural, la oferta, recaía sobre los estados de la periferia.

Es de la mano de Occidente, como líder del orden social hegemónico estructurante de las relaciones internacionales contemporáneas, que las sustancias psicoactivas se vuelven mercancías globales liberalizadas para pasar luego a la ilegalidad. Es, por tanto, en la dimensión jerárquica del sistema internacional donde encontramos el origen y expansión del "narcotráfico".

\section{Conclusiones}

Las estructuras históricas internacionales jerárquicas han determinado la evolución de las

\footnotetext{
87 ROSSI, Adriana, Narcotráfico y Amazonia ecuatoriana, Abya-Yala, Quito, Ecuador, 1997.

${ }^{88}$ ESCOHOTADO, Antonio, Historia elemental...op.cit., p. 181.

89 WOODIWISS, Michael y BEWLEY-TAYLOR, David, "La Componenda Global...op.cit.
} 
sustancias psicoactivas: primero como imposición de mercado por parte de las potencias expansionistas europeas, promoviendo su producción, comercio y consumo; luego por la capacidad de las industrias farmacéuticas capaces de potenciar esas mercancías de origen natural. Occidente instala a escala planetaria un mercado libre para las drogas durante el s. XIX, generando un uso masivo en los consumidores alrededor del mundo.

El giro hegemónico que se producirá en el s. XX permitirá el ascenso como superpotencia de EEUU. Como garante del orden social hegemónico impondrá su visión del mundo acerca de las sustancias psicoactivas, que se tornaron definitivamente ilegales.

Dos contradicciones medulares destacan en la dinámica prohibicionista: el excesivo centramiento en sustancias de origen natural, producidas en la periferia -colonial y poscolonial- y una mayor permisividad para sustancias originadas en laboratorios del centro. El incremento de la prohibición tuvo como contracara la expansión y diversificación del mercado ilícito de drogas; a mayor represión y control le correspondió un incremento y dispersión de áreas y grupos a cargo de la oferta global, en respuesta a una demanda instalada.

A pesar de todas sus paradojas este paradigma prohibicionista rige el sistema normativo internacional hasta hoy. Señalamos como claves de la evolución de sustancias psicoactivas a nivel global:

a) El surgimiento de la mayoría de las drogas hoy consideradas ilícitas fue en un marco de legalidad. Los productos descubiertos por la industria farmacéutica fueron considerándose peligrosos a partir del s. XX pero durante todo el s. XIX se garantizó libertad de circulación y consumo para los mismos.

b) La ampliación de esta industria y estos productos a escala internacional no hubieran sido posibles sin la expansión europea y, más tarde, norteamericana de ultramar y el surgimiento de un mercado mundial.

c) A medida que creció la alarma acerca de las consecuencias o posibles amenazas individuales y colectivas sobre las drogas se instaló una ola prohibicionista para impedir su disponibilidad. Sin embargo, el mercado ya desarrollado no cesó. A la demanda en crecimiento respondió una oferta ilegal asociada a grupos criminales que complejizaron la realidad del consumo y tráfico de drogas.

d) Estos grupos encargados del gran negocio lograron insertarse en las tramas institucionales, políticas y económicas, nacionales e internacionales, pudieron readaptarse y utilizar para su beneficio las diferentes realidades internacionales a lo largo del s. XX.

e) El circuito ilegal de drogas no está aislado del sistema internacional sino firmemente inserto en él. No es una amenaza desde fuera sino parte inmanente del mismo. Las instituciones de este sistema, así como las de los propios estados y mercados que lo componen, se entrecruzan en un doble juego que intenta restringirlo pero a la vez le abre puertas para su funcionamiento.

Podemos concluir que el narcotráfico es, sin duda, un fenómeno complejo, que abarca todas las aristas de la realidad internacional y que requiere un enfoque de mayor profundidad $y$, en especial, de mayor diversidad. El reconocimiento de la responsabilidad compartida e histórica es un paso necesario para establecer prácticas y normas que puedan 
disminuir los niveles de violencia y corrupción asociados, con especial consideración a los sectores vulnerables involucrados así como los derechos de los consumidores, evitando la criminalización generalizada de campesinos y usuarios.

\section{Bibliografía}

ARMSTRONG, Karen, Los Orígenes del Fundamentalismo en el Judaísmo, el Cristianismo y el Islam, Barcelona, TUSQUETS, 2004.

ATEHORTÚA CRUZ, Adolfo León y ROJAS RIVERA, Diana Marcela, "El narcotráfico en Colombia. Pioneros y Capos" en Revista Historia y Espacio, no 31, 2008.

BETANCOURT, Darío, GARCÍA, Martha, Contrabandistas, Marimberos y Mafiosos. Historia social de la mafia colombiana, Colombia, Tercer Mundo Editores, 1994.

CONVENIO INTERNACIONAL DEL OPIO, firmado en La Haya, 1912. Disponible en: http://www. filosofia. org/mon/dro/1912cio.htm [Consultado el 15 de Noviembre de 2017]

COURTWRIGHT, David T., "Una breve historia de políticas sobre drogas, o por qué declaramos la guerra a unas drogas y no a otras" en History Faculty Publications, University of North Florida, 2012. Disponible en http://www.uniad.org.br/interatividade/artigos/item/16849-una-breve-historiade-poli\%CC\%81ticas-sobre-drogas-o-por-que\%CC\%81-declaramos-la-guerra-a-unas-drogasy-no-a-otras [Consultado el 07 de Mayo de 2017]

COX, Robert W., Approaches to world order, Cambridge University Press, Cambridge, 1996.

COX ROBERT W., "Fuerzas sociales, estados y órdenes mundiales: Más allá de la Teoría de Relaciones Internacionales" en Revista Relaciones Internacionales, no 24, 2014, pp: 129-162.

DE REMENTERÍA, Ibán, "Prevenir en drogas: paradigmas, conceptos y criterios de intervención", CEPAL, División desarrollo social, septiembre, Santiago de Chile, 2001.

DEL OLMO, Rosa, Los discursos sobre la droga, Hisbol, Bogotá, 1988.

DEVETAK, Richard, "Critical Theory" en BURCHILL, Scott et al, Theories of International Relations, Pallgrave Mcmillan, Nueva York, 2005.

ESCOHOTADO, Antonio, Historia elemental de las drogas, Anagrama, Barcelona, 1996.

ESCOHOTADO, Antonio, "Sobria Ebriedad" en El País, 16 de Julio, 1994. Disponible en https://elpais. com/diario/1994/06/16/sociedad/771717615 850215.html [Consultado el 30 de Junio de 2010]

ESCOHOTADO, Antonio, "La prohibición principios y consecuencias" en de MELO RIBEIRO Maurides y SEIBEL Sergio D., Drogas, hegemonía do cinismo, Memorial, San Pablo, Brasil, 1997.

ESCOHOTADO, Antonio, Toxicomanías, Artículos, 2003. Disponible en www.escohotado.org [Consultado el 10 de Agosto de 2017]

GABANTXO, Kontxi, "Antecedentes históricos, situación actual y tendencias de consumo" en Cuadernos de Ciencia de la Salud, no 4, Sociedad de Estudios Vascos, España, 2001, pp: 139-158.

GOOTENBERG, Paul, "Hablar como el Estado: Flujo de Drogas y discursos estatales de control" en Apuntes de Investigación del CECYP, Año XIII, Vol. 24, no 1, pp: 13-49. Disponible en http:// www.apuntescecyp.com.ar/index.php/apuntes/article/view/471 [Consultado el 20 de Junio de 2017]

GOOTENBERG, Paul, "Cocaine's long march North" en Latin American Politics and Society, vol. 54, no 1, Primavera, 2012, pp: 159-180.

HARRISON NARCOTIC TAX ACT, EEUU, 1914. Disponible en http://www.druglibrary.org/schaffer/library/ studies/cu/cu8.html [Consultado el 22 de Noviembre de 2017]

HOBSBAWM, Eric, La era del Capital (1848-1875). La era del Imperio (1875-1914), Crítica, Buenos Aires, 2012.

JELSMA, Martin y KRAMER, Tom, "Síntomas de abstinencia: cambios en el mercado de las drogas del Sudeste Asiático" en Drogas y Conflicto, Documentos de Debate no 16, Transnational Institute Briefing Series $n^{0} 1,2008$. Disponible en https://www.tni.org/files/download/debate16s.pdf [Consultado el 13 de Julio de 2017]

LÓPEZ RESTREPO, Andrés, "Por tu bien, y sobre todo por el mío: fundamentos y altibajos del prohibicionismo estadounidense" en Análisis Político, no 46, Universidad Nacional de Colombia, mayo-agosto, 2002, pp: 4-24. Disponible en http://biblioteca.clacso.edu.ar/ar/libros/colombia/ assets/own/analisis46.pdf [Consultado el 08 de Mayo de 2017]

Mc ALLISTER, William B., Drug Diplomacy in the Twentieth Century. An International History, Routledge, Nueva York, 2002.

Mc COY, Alfred, The politics of heroin in Southeast Asia, Harper Colopohon Books, Nueva York, 1973.

MODELSKI, George, "Long Cycles in Global Politics" en WIENER, Jarod y SCHRIRE, Robert, International Relations, vol 1, UNESCO/EOLSS, UK, 2009, pp: 230-252.

NACIONES UNIDAS, UNDOC, Convención Única sobre Estupefacientes, 1961. Disponible en https:// 
www.unodc.org/pdf/convention_1961_es.pdf [Consultado el 25 de Julio de 2017]

NACIONES UNIDAS, UNDOC, Convenio sobre Sustancias Psicotrópicas, 1971. Disponible en https:// www.unodc.org/pdf/convention_1971_es.pdf [Consultado el 25 de Julio de 2017]

NACIONES UNIDAS, UNDOC, Convenio contra el Tráfico Ilícito de Estupefacientes y Sustancias Psicotrópicas, 1988. Disponible en https://www.unodc.org/pdf/convention_1988_es.pdf [consultado el 18 de Enero de 2018.]

ORGANIZACIÓN MUNDIAL DE LA SALUD, Managment of Substance Abuse, "WHO Lexicon of alcohol and drug terms". Disponible en http://apps.who.int/iris/bitstream/10665/39461/1/9241544686_ eng.pdf [Consultado el 13 de Agosto de 2017]

RENOUVIN, Pierre, Historia de las Relaciones Internacionales Siglos XIX y XX, Akal, Madrid 1989.

ROSSI, Adriana, 1997, Narcotráfico y Amazonia ecuatoriana, Abya-Yala, Quito, 1997.

ROSSI, Adriana, "Narcotráfico, entre Ilegalidad, Legitimidad y Funcionalidad", ponencia presentada en la Conferencia Nacional sobre Políticas de Drogas, Visión y Actores del debate, 17-18 Septiembre, Buenos Aires, 2003.

SAID, Edward, Cultura e Imperialismo, Anagrama, Barcelona, 1996.

SANDOVAL RAMIREZ, Luis, "La hegemonía mundial de las potencias: una aproximación teórica" en Problemas del Desarrollo, vol. 33, no 131, UNAM, México, 2002, pp: 98-129. Disponible en http://www.revistas.unam.mx/index.php/pde/issue/view/674/showToc [Consultado el 22 de Julio de 2017]

SANTINO, Humberto, LA FIURA, Giovanni, Detrás de la Droga, Homo Sapiens, Rosario, 1993.

THOUMI, Francisco E., "La normatividad internacional sobre drogas como camisa de fuerza", en Nueva Sociedad, no 222, julio-agosto, 2009, pp: 42-49. Disponible en http://nuso.org/articulo/lanormatividad-internacional-sobre-drogas-como-camisa-de-fuerza/ [Consultado el 21 de Julio de 2017]

TOKATLIÁN, Juan Gabriel (comp.), Drogas y Prohibición: una vieja guerra, un nuevo debate, Libros del Zorzal, Buenos Aires, 2009.

TRASNATIONAL INSTITUTE, "Las Convenciones de Drogas de la ONU", 2015. Disponible en https:// www.tni.org/files/publication-downloads/primer_unconventions_24102015-es.pdf [Consultado el 12 de Agosto de 2017]

WALERSTEIN, Immanuel, Análisis de Sistemas-Mundo: una introducción, Siglo XXI Editores, México DF, 2005.

WOODIWISS, Michael y BEWLEY-TAYLOR, David, "La Componenda Global. La construcción de un régimen global de control" en Transnational Institute. Briefing Series, Programa Crimen y Gobalización, no 3, 2005. Disponible en https://www.tni.org/files/download/crime2s-1.pdf [Consultado el 12 de Agosto de 2016] 


\section{RELACIONES INTERNACIONALES}

Revista académica cuatrimestral de publicación electrónica Grupo de Estudios de Relaciones Internacionales (GERI) Universidad Autónoma de Madrid, España

www.relacionesinternacionales.info

ISSN 1699 - 3950

ff facebook.com/RelacionesInternacionales

twitter.com/RRInternacional 